\title{
Correction to: Sodium Zirconium Cyclosilicate: A Review in Hyperkalaemia
}

\author{
Sheridan M. Hoy ${ }^{1}$
}

Published online: 20 March 2019

(c) Springer Nature 2019

\section{Correction to: Drugs (2018) 78:1605-1613 https://doi.org/10.1007/s40265-018-0991-6}

The article Sodium Zirconium Cyclosilicate: A Review in Hyperkalaemia, written by Sheridan M. Hoy, was originally published Online First without open access. After publication in volume 78, issue 18, pages 1605-1613 AstraZeneca Pharmaceuticals, LP requested that the article be Open Choice to make the article an open access publication. Postpublication open access was funded by AstraZeneca Pharmaceuticals, LP. The article is forthwith distributed under the terms of the Creative Commons Attribution-NonCommercial 4.0 International License (http://creativecommons .org/licenses/by-nc/4.0/), which permits any noncommercial use, duplication, adaptation, distribution and reproduction in any medium or format, as long as you give appropriate credit to the original author(s) and the source, provide a link to the Creative Commons license and indicate if changes were made.

The original article has been corrected.

Open Access This article is distributed under the terms of the Creative Commons Attribution-NonCommercial 4.0 International License (http://creativecommons.org/licenses/by-nc/4.0/), which permits any noncommercial use, distribution, and reproduction in any medium, provided you give appropriate credit to the original author(s) and the source, provide a link to the Creative Commons license, and indicate if changes were made.
The original article can be found online at https://doi.org/10.1007/ s40265-018-0991-6.

Sheridan M. Hoy

demail@springer.com

1 Springer, Private Bag 65901, Mairangi Bay, Auckland 0754, New Zealand 